\title{
As concepções educacionais de Martinho Lutero*
}

Luciane Muniz Ribeiro Barbosa

Faculdade Montessori de Educação e Cultura

Correspondência:
Luciane Muniz R. Barbosa
Rua Parnamirim, 20 apto 11
05331-020 - São Paulo - SP

e-mail: lumuniz@usp.br

\section{Resumo}

Este artigo tem como objetivo apresentar a concepção de educação de Martinho Lutero no movimento da Reforma Protestante do século XVl, revelando aproximações entre história, religião e política. Em um século marcado por inúmeras indagações e mudanças, Lutero apresenta críticas em prol de uma Reforma na lgreja e também faz propostas para uma reforma da educação escolar de sua época, até então marcada pela formação exclusiva de religiosos e eclesiásticos. Ele propõe, em dois textos de sua autoria, uma educação escolar cristã que apresente uma nova organização em relação a: currículos, métodos, professores, formas de financiamento e manutenção das escolas. Também reflete sobre a utilidade dessa educação e propõe que ela: atenda a todos; seja criada e mantida pelas autoridades públicas e não mais pela lgreja; seja de freqüência obrigatória, para a qual apela aos pais e às autoridades por essa tarefa. Ainda que algumas dessas características não apresentem Martinho Lutero como precursor, é inevitável o reconhecimento de que ele, aliado à figura de Filipe Melanchthon e às transformações ocorridas em seu tempo, contribuiu significativamente para a extensão do direito à Educação, marcada sobretudo em sua proposta de criação das escolas elementares, além da reorganização dos colégios secundários e da universidade, enfatizando a ação do Estado como responsável pela educação escolar.

\section{Palavras-chave}

Martinho Lutero - Reforma protestante - Direito à Educação - Estado e Educação.

'Texto adaptado do Trabalho Complementar de Curso apresentado à Faculdade de Educação da Universidade de São Paulo (FEUSP) como requisito parcial para a obtenção da graduação em Pedagogia, desenvolvido sob orientação do Prof. Dr. Romualdo Luiz Portela de Oliveira. Participaram da banca examinadora: Profa. Dra. Maria Lucia Spedo Hilsdorf e Profa. Dra. Beatriz Alexandrina de Moura Fétizon. 


\section{The educational conceptions of Martin Luther*}

Luciane Muniz Ribeiro Barbosa

Faculdade Montessori de Educação e Cultura

Contact:

Luciane Muniz R. Barbosa

Rua Parnamirim, 20 apto 11

05331-020 - São Paulo - SP

e-mail: Iumuniz@usp.br

\section{Abstract}

This article presents Martin Luther's conception of education in the $16^{\text {th }}$ century Protestant Reform, revealing associations between history, religion, and politics. In a century marked by countless quests and changes, Luther offers criticisms in favor of a Reform of the Church, and also makes proposals for a reform of the school education of his time, hitherto characterized by the exclusive formation of religious and ecclesiastic men. He proposes in two of his texts a Christian schooling that shows a new organization with respect to curricula, methods, teachers, and forms of funding and maintenance of schools. He also reflects upon the usefulness of such education, and suggests that: it should be open to everyone; be created and maintained by public authorities and not by the Church; that it should be mandatory, for which task he appeals to parents and authorities. Even if some of these features may not have Luther as their precursor, there is no escape recognizing that he has, together with Philipp Melanchton and the transformations occurred during his time, contributed decisively to the extension of the right to education, particularly notable in his proposal for the creation of elementary schools, apart form the reorganization of secondary school and the university, emphasizing the role of the State as responsible for school education.

\section{Keywords}

Martin Luther - Protestant Reform - Right to Education - State and Education.
"This text was adapted from the Final Work presented to the Faculty of Education of the University of São Paulo - FEUSP - as part of the requirements of the undergraduate course in Pedagogy. The work was supervised by Professor Romualdo Luiz Portela de Oliveira; the evaluation committee also included Professors Maria Lucia Spedo Hilsdorf and Beatriz Alexandrina de Moura Fétizon. 
Como sempre, recusar uma reforma é um convite à Revolução.

(Laski, 1973, em "O liberalismo europeu")

A história da Educação e a história da lgreja mostram-se articuladas sendo, em determinados momentos, fonte de influências recíprocas. Foi na ldade Média que essa relação se mostrou ainda mais intensa sendo a lgreja a única encarregada pela educação escolar que visava à garantia da instrução de seus clérigos, ou seja, bispos e abades procuravam formar crianças e jovens com aspirações à vida religiosa.

Dessa maneira, desde o século $\mathrm{V}$, a instrução escolar passa a estar estreitamente ligada às ações da lgreja, sendo ela a responsável pela sua organização e manutenção. Paul Foulquié (1957) afirma que a formação cristã era o essencial da Educação nesse período e os pais que desejassem oferecer instrução aos seus filhos eram obrigados a enviá-los para as aulas que preparavam os futuros clérigos. Por ordem do Papa e do Concílio, a lgreja passa a abrir suas escolas também para as demais crianças e jovens e "mostra-se zelosa sobretudo em proporcionar a gratuidade do ensino e a colação de graus” (p. 31).

Surgem, então, categorias de escolas eclesiásticas mantendo público e objetivos específicos para a própria lgreja: as escolas catedrais ou episcopais, que formavam novos pregadores e posteriormente se abriram (em 529, no Concílio de Vaison) para as populações do campo; as escolas monacais ou claustrais, ligadas aos conventos, que se transformaram nas mais importantes instituições de ensino entre os séculos V e Xl; e as escolas catedrais ou episcopais ligadas às catedrais das cidades, que reaparecem como um surto no século XII, acompanhando o movimento do renascimento urbano.

Data do início do século XV1 a criação dos colégios secundários que ofereciam, aos jovens, estudo preparatório para ingresso nas universidades e que se transformaram, como observa Ruy Nunes (1980), em veículos do humanismo. Essa é a época em que os príncipes dos estados emergentes passam a apoiar a nova forma de educação escolar, visando à estabilização de suas cortes e à formação de seus cortesãos. Foulquié (1957) reforça essa idéia localizando no Antigo Regime, a partir do século XVI com os movimentos da Renascença e da Reforma, o período em que os príncipes quiseram "dominar as Universidades e, de maneira geral, se ocuparam com o ensino que começaram a considerar como público" (p. 47). Contudo, essa instrução escolar, como já explicitado, se destinava ao público que teria acesso à universidade.

A Educação medieval, que tinha como pressuposto uma formação religiosa e intelectual e que, nas universidades, visava um ensino prático com objetivo profissional, no início da ldade Moderna, passa, segundo Nunes (1980), por profundas mudanças em suas concepções e meios de alcançar seus objetivos: a educação começa "a visar de modo claro e definido à formação integral do homem, o seu desenvolvimento intelectual, moral e físico" (p. 41).

A Educação, sob influência do movimento humanista que se expandia, sofreu diversas mudanças e desenvolveu características particulares nos diferentes países nos séculos em que as tradições medievais foram suprimidas pelos novos ideais do Renascimento. Contudo, a Educação do século XVl, como será mostrada adiante, continuou apresentando um caráter cristão.

0 que se pretende analisar, portanto, são as propostas que, no contexto do movimento da Reforma Protestante, Martinho Lutero (14831546), monge da ordem de Santo Agostinho, apresenta em defesa da reforma do ensino secundário e da universidade e da criação de escolas de educação elementar que atinjam toda a população.

As concepções de Lutero sobre Educação, principalmente sobre uma educação cristã, acabam perpassando todos os seus tratados e escritos na medida em que neles expõe e ataca os problemas da lgreja e também da sociedade, aconselhando-as como deveriam ser. Contudo, é em dois textos específicos que ele registra sua posição sobre a educação escolar: Aos conselhos de todas as cidades da Alemanha para que criem e mantenham esco- 
las cristãs, carta escrita em 1524, e Uma prédica para que se mandem os filhos à escola, sermão proferido em 1530. Esses dois escritos serão tomados como fonte principal para a análise da educação escolar proposta por Martinho Lutero na tentativa de compreender a concepção de Educação por ele apresentada em suas propostas de reforma.

Os dois textos citados representam, de certa forma, o quanto Lutero fez suas propostas e interferências baseadas sobretudo na sua doutrina dos dois reinos, ou seja, o quão relevante seria, tanto para o Estado (a "mão esquerda de Deus") como para a lgreja (sua "mão direita”), pais compromissados e cidadãos bem-educados para atuarem no governo secular e espiritual.

Neles, Lutero apresenta não somente questões de caráter conceitual e os princípios contidos em sua proposta de reforma do sistema escolar, mas orienta sobre a forma como deveria ser organizado esse novo ensino que propõe que seja para todos. No entanto, estudiosos afirmam que, apesar de ele esclarecer em seus tratados diversos pontos sobre a forma como deveria se dar esse ensino escolar, eles "não chegam a formular uma teoria cristã de educação” (Beck apud Lutero, 1995, p. 301).

Ricardo Rieth compartilha dessa idéia afirmando que "Lutero não teve por objetivo desenvolver uma teoria da educação em perspectiva cristã. Quis, isso sim, seguir estimulando a sociedade a empenhar-se por uma educação formal de qualidade" (apud Lutero, 2000, p. 5), baseada na compreensão que ele tinha da atuação de Deus no mundo por meio dos dois governos.

Antes de iniciar as análises específicas sobre essas questões educacionais, cabe ressaltar que, atualmente, os estudos sobre Lutero têm atingido outros círculos que não somente o da história da lgreja reformada. Essa conquista deve-se graças às recentes publicações em língua portuguesa dos textos de sua autoria e ao contato com a bibliografia estrangeira que continua desenvolvendo estudos sobre Lutero e as questões que o envolvem.

\section{Influências}

Mediante a análise de obras de história da Educação, pode-se constatar que as orientações de Lutero sobre a forma de organização da educação escolar, tanto para os colégios de ensino secundário e para a universidade como em sua proposta de criação das escolas elementares, sofreram forte influência de seu amigo Filipe Melanchthon (1497-1560), sendo difícil saber de fato a autoria e originalidade de algumas de suas idéias.

Lutero conhece Melanchthon em 1518 e torna-se, conforme sua própria declaração, seu amigo até a morte. Melanchthon o teria acompanhado durante todas as fases da Reforma, tornando-se uma pessoa fundamental para Lutero no período em que traduziu a Bíblia e servindo de consultor sobre o grego e sobre as passagens bíblicas.

É Melanchthon o responsável por introduzir na universidade, com os estudos sobre os clássicos gregos e latinos, uma nova forma de ensinar muito diferente da da escolástica. Para explicitar sua importante atuação nas reformas na universidade, Ruy Nunes (1980) afirma que

[...] restaurou-se a aliança da reforma com o humanismo graças ao talento e ao esforço de Melanchthon que tornou a Universidade de Wittenberg a mais popular da Germânia e facho iluminante de humanismo e teologia. (p. 64)

É sob iniciativa e orientação de Melanchthon que o Conselho de Nürenberg funda, em 1526, o Ginásio de Egídio ao lado de três escolas de latim já existentes na cidade. Dada sua capacidade de promoção e organização das escolas, ele ficou conhecido como o 'preceptor da Germânia’ e, segundo Franco Cambi (1999), "a elaboração das estruturas organizativas e dos conteúdos culturais próprios das escolas secundárias da Reforma é devida sobretudo a Filipe Melanchthon" (p. 250), que tentava efetuar uma convergência entre humanismo e luteranismo. 
Não há dúvidas de sua relevância e influência na vida de Lutero, no próprio desencadeamento da Reforma proposta para a lgreja e principalmente para a ocorrida na organização das escolas, sobretudo as de ensino secundário. Nunes (1980) expressa bem essa relação afirmando que "[...] Lutero prescreve as normas fundamentais para a organização das escolas”, entretanto, é Filipe Melanchthon

[...] o ministro da educação de Lutero. Escreveu manuais escolares, organizou o sistema escolar de Saxe, redigiu juntamente com Lutero as Diretivas aos inspetores escolares e o livro Visita das Escolas, reorganizou as universidades de Marburg, Koenigsberg, lena, Halmstadt, Dorpat, Leipzig e Heidelberg, e dava orientação e assistência aos mestres luteranos da Germânia. (p. 100-101)

No ensino elementar, Lorenzo Luzuriaga (1959; 1963) destaca Johannes Bugenhagen (1485-1558) como colaborador de Lutero e responsável pela inspiração de uma série de ordenações municipais no norte da Alemanha onde ele, em processo de reorganização das igrejas da região, estabelece diversos preceitos sobre a educação pública. Em todos esses estatutos religiosos, de diferentes cidades do norte da Alemanha,

[...] se recomenda e ordena a criação de escolas, ao ponto de haver-se chamado Bugenhagen de pai da Escola primária pública alemã, embora também predominasse nele a consideração eclesiástica. (Luzuriaga, 1959, p. 08)

Nunes (1980) afirma ter sido Bugenhagen o "mais ardente defensor da reforma da lgreja alemã”, após ter aderido ao luteranismo em 1520. Ele também teria ajudado Lutero no seu trabalho de tradução da Bíblia e pronunciado sua oração fúnebre; pois "labutou ardentemente a favor do luteranismo” (p. 178). No entanto, na questão educacional, apesar de, na avaliação de
Nunes, ter superado Lutero e Melanchthon quanto às realizações em prol das escolas protestantes germânicas, seus planos escolares

[...] não conseguiram, no fim das contas, implantar a escola popular na Alemanha do século XV1, uma vez que a Guerra dos Trinta Anos acabou com esses primeiros e animosos ensaios de renovação escolar. (p. 179)

\section{Organização do sistema escolar}

0 que se pode constatar, então, é que, ainda que sob influência e auxílio de seus amigos e colaboradores, Lutero também toma para si a luta por uma reforma no ensino da época e registra suas orientações sobre a forma como o sistema escolar deveria ser organizado, procurando responder, entre outras, questões como: 0 que deve ser ensinado às crianças e aos jovens? De que forma esse ensino deve ser ministrado? Como a escola deve ser financiada? Quem e como devem ser os mestres? Onde e em que período as crianças deverão estudar?

Ao analisar esses diversos pontos, o primeiro aspecto a ser ressaltado é o fato de Lutero propor a criação e manutenção de escolas cristãs. Segundo Martin Volkmann (1984),

[...] para Lutero ainda era óbvio que todas as pessoas fossem cristãs. Na sua época ainda não havia o que hoje conhecemos por secularização. As autoridades seculares, mesmo no exercício de sua função específica, não deixavam de ser cristãos. (p. 97)

Diante desse argumento e do fato de o Estado daquele momento possuir um caráter cristão, explícito na doutrina dos dois reinos, ressalta-se que Lutero requer a criação de escolas que tenham a Bíblia como o centro do ensino e que formem bons cristãos para atuarem na sociedade, quer seja como pastores comuns na pregação do Evangelho ou como autoridades da vida secular. 
A propósito dos conteúdos e temas propostos por Lutero para compor o currículo das novas escolas cristãs, bem como da organização da estrutura de ensino no que diz respeito aos métodos e professores, muitas vezes não ficou explícito, nos escritos analisados, a qual grau do ensino se destina, ou seja, ele não afirma claramente o que é recomendado para o ensino elementar, para os colégios de ensino secundário ou para as universidades. Por esse motivo, a distinção se torna possível muito mais por leitura de historiadores da Educação do que pelos escritos específicos de Lutero. Dessa maneira, optou-se por apresentar, em cada um dos temas expostos a seguir, as propostas contidas nos dois textos analisados e, posteriormente, explicitar a separação que seus comentaristas lhe atribuem para os níveis de ensino, bem como a discussão apresentada por eles sobre cada item.

\section{Currículo}

Em seus escritos, Lutero apresenta uma nova proposta para o currículo escolar, após críticas de que o ensino, principalmente nas universidades, baseava-se, até então, nas obras de Aristóteles que, com livros nocivos, levava as pessoas para mais longe da Bíblia - em uma crítica ao sistema medieval que se baseava na filosofia de Aristóteles - e na qual nada de útil se aprendia:

Afinal, que se aprendeu até agora nas universidades e conventos a não ser tornar-se burro, tosco e estúpido? Houve quem estudasse vinte, quarenta anos e não saiba nem latim nem alemão. (Lutero, 1995, p. 306)

0 novo currículo proposto tem a Bíblia como cerne do ensino e, como conseqüência desse fato, para melhor estudá-la, Lutero defende, como algo indispensável para as novas escolas, o ensino das línguas antigas. Principalmente no tratado de 1524, apresenta vários argumentos sobre a importância de se aprender o hebraico e o grego, línguas consideradas santas e necessárias para um estudo mais aprofundado do Velho e do Novo Testamento, além do estudo do latim, o que se mostrou indicado para o ensino secundário na proposta dos colégios humanistas.

Apesar de, nesse momento, Lutero (1995) já ter traduzido parte da Bíblia e estar trabalhando para a tradução de toda a Escritura, demonstrando ser o incentivador maior da leitura da Bíblia na língua alemã, ele afirma que conhecer as línguas clássicas e estudá-las seria fundamental para tratar a Escritura com autonomia e combater os que a interpretam erroneamente. Além disso, para ele

[...] a fé e o Evangelho podem ser pregados por simples pregadores sem conhecimentos lingüísticos; no entanto é uma coisa pobre e miserável, e por fim a gente cansa e se enfada e assim somos seduzidos. Onde, porém, há conhecimento das línguas, aí as coisas se desenvolvem com frescor e vigor, e a Escritura é trabalhada; aí a fé se encontra sempre de forma nova por meio de outras e mais outras palavras e obras. (p. 316)

A valorização de Lutero ao ensino das línguas clássicas mostra-se como conseqüência dos ideais do movimento humanista com a propagação do Renascimento na Alemanha e também como forma de alcançar o que pregava como seu objetivo inicial: que os cristãos tivessem não somente livre acesso à Bíblia, mas fossem capazes e tivessem condições de interpretá-la sem mediação. A aprendizagem das línguas seria, então, um instrumento para a garantia da liberdade do cristão no conhecimento da Escritura.

Para a conquista desse objetivo, a língua nacional também é valorizada, tanto que Lutero propõe a leitura da Bíblia em língua vernácula para o aprendizado das crianças no ensino elementar. Contudo, isso não bastaria. Era fundamental que se estudasse latim, grego e hebraico, além do ensino da gramática e a leitura de textos mediante o estudo de obras literárias pagãs e cristãs. 
Apesar de a educação escolar de Lutero (1995), especificamente para o secundário, apoiar-se, sobretudo, no aprendizado das línguas antigas, ele também recomenda o estudo das ciências, das artes liberais e da história. É dada uma ênfase ao ensino de história, visto que por meio dela as crianças poderiam conhecer a sabedoria de todo o mundo e

[...] isto thes serviria de orientação para seu pensamento e para se posicionarem dentro do curso do mundo com temor de Deus. Além disso a História os tornaria prudentes e sábios, para saberem o que vale a pena perseguir e o que deve ser evitado nesta vida exterior, e para poderem aconselhar e governar a outros de acordo com estas experiências. (p. 319)

Também chega a recomendar o ensino de música, com toda a matemática necessária, a jurisprudência e a medicina, entendidas essas duas últimas como sendo recomendação para a universidade.

Alguns autores apresentam uma distinção clara do que era contemplado no currículo do ensino elementar e do secundário. Segundo Antônio Frago (1993), pode-se perceber a estrutura do currículo nos diferentes Estados alemães como: "os catecismos para as escolas [elementares] e a Bíblia em latim e grego para os ginásios [de ensino secundário]" (p. 48), sendo que os catecismos se propunham a ensinar, sobretudo, a doutrina da nova igreja.

Maria Lúcia Hilsdorf (2006) confirma essa separação afirmando que, ao longo do século XVl, as escolas de confissão reformada reorganizaram-se sendo que:

[...] a maioria delas adotou a orientação humanista segundo o programa definido em 1528 por Melanchthon, baseado na doutrina, no latim e na retórica escrita, dando origem aos colégios reformados de humanidades. As demais se organizaram, a partir dos meados do século, pelo padrão das pequenas escolas, com ensino das primeiras letras em alemão, contas, música e doutrina. (p. 167)

Vale ressaltar que o currículo existente por longo período na ldade Média era o que envolvia os conteúdos do trivium e quadrivium (as Sete Artes Liberais) ${ }^{1}$, mas já na concepção dos humanistas, a educação era baseada nos studia humanitatis que abrangiam as disciplinas de Gramática, Retórica, Poética, História e Filosofia Moral e devia ser completada com o estudo das obras dos santos padres da lgreja (principalmente Santo Agostinho) e de matemática, astronomia, demais ciências, música, dança e outras artes e exercícios físicos (Nunes, 1980).

Outra questão importante que envolve o currículo e que foi objeto de discussão por Lutero (1995) foram os livros que deveriam compor as bibliotecas das escolas e universidades. Ele pede àqueles que aceitassem criar e manter as escolas que "não poupem esforços nem dinheiro para a instalação de livrarias ou bibliotecas” (p. 322), para que o Evangelho pudesse ser conservado por meio da preservação dos livros e para que os príncipes espirituais e seculares tivessem literatura para ler.

Julga os livros da época (incluindo os de Aristóteles) como sujos e venenosos e questiona:

Não foi uma tristeza lamentável que até agora um menino tivesse que estudar vinte anos ou mais somente para aprender um mau latim, suficiente apenas para tornar-se padre e ler a missa? [...] Que era de se esperar a não ser alunos e mestres tolos como os livros que ensinavam? Uma gralha não produz uma pomba, e um tolo não produz um sábio. Esta é a recompensa da ingratidão, por não se ter dedicado esforço à criação de bibliotecas, mas porque se deixaram

1. As Artes Liberais, conjunto das sete disciplinas que constituíam a formação na Idade Média, eram divididas no Trivium - compreendendo Gramática, Retórica, Dialética - e no Quadrivium - Aritmética, Geometria, Astronomia, Música. 
perder os bons livros e se preservaram os inúteis. (Lutero, 1995, p. 323)

Dessa forma, ele orienta que a preocupação não deveria ser com a quantidade de livros, mas com a seleção daqueles que se mostram importantes, a saber: em primeiro lugar, a Sagrada Escritura em latim, grego, hebraico, alemão e outras línguas; depois os melhores e os mais antigos intérpretes da Bíblia, ambos em grego, hebraico e latim; depois os livros úteis como os poetas e oradores para aprender as línguas e a Gramática, independente de serem gentios ou cristãos, gregos ou latinos; depois os livros sobre as artes liberais e outras disciplinas; entre os mais importantes deveriam constar as crônicas e os compêndios de História; e por último, livros jurídicos e de Medicina, fazendo-se uma boa seleção entre eles (Lutero, 1995).

Essa seleção dos livros completa o que ele propunha para o currículo das escolas e universidades reformadas, sendo sua forte posição contra Aristóteles, na interpretação de Timothy George (1993), sua própria campanha contra a teologia escolástica da época e a favor de seus planos de reforma no currículo:

Lutero não tinha nada contra Aristóteles em si. 0 que ele rejeitava era todo o esforço da teologia escolástica de fazer da filosofia aristotélica a pressuposição da doutrina cristã, de interpretar a revelação bíblica relativamente à 'sofística' pagã, de reduzir os grandes temas das Escrituras - graça, fé, justificação - à algaravia escolástica. (p. 59)

\section{Métodos}

Por ter recebido uma educação baseada na escolástica medieval e estando em contato com as inovações propostas pelo Humanismo, Lutero (1995) faz uma crítica severa ao ensino nas universidades e nos conventos e reivindica a aplicação de novos métodos no processo educativo:
[...] se as universidades e conventos continuarem como estão, sem a aplicação de novos métodos de ensino e modos de vida para os jovens, preferiria que nenhum jovem aprendesse qualquer coisa e ficassem mudos. (p. 306)

Como sugere Walter Altmann (1994), "Lutero, em geral, aceitou os princípios pedagógicos da escola humanista” (p. 206), sendo essa constatação prova da forte influência do humanista Felipe Melanchthon, levando Franco Cambi (1999) a afirmar que

[...] o modelo de cultura que o movimento reformador tem em mira para organizar as próprias escolas é o humanístico, baseado na prioridade das línguas e na centralidade da educação gramatical. (p. 248)

Contudo, cabe ressaltar que, apesar das propostas pedagógicas de Lutero se assemelharem em partes à dos pedagogos humanistas, seus objetivos diferiam dos desses autores e, embora se aproximasse de humanistas como Melanchton, ele não chegou a se declarar um humanista.

Maria Lúcia Hilsdorf (2006) apresenta uma posição distinta em relação a essa aproximação, defendendo que Lutero não seguia a linha humanista na sua prescrição do que deveria ser a escolarização da infância protestante na escola elementar, chegando a afirmar que tal escolarização é possível que "fosse baseada na catequese da doutrina, ao que parece, mais próxima dos saberes da lgreja do que dos saberes ligados aos ofícios" (p. 168, grifo meu).

Na proposição de novos métodos, Lutero (1995) opõe-se ao antigo sistema escolar baseado em punições físicas e pressões psicológicas que causavam sofrimento aos alunos (ou seja, a disciplina severa que recebeu na educação familiar e escolar). Questiona mesmo a disciplina rígida com que os pais educavam os filhos afirmando que

[...] quando a disciplina é aplicada com maior rigor e tem algum resultado, o máximo que se alcança é um comportamento força- 
do ou de respeito; no mais continuam sendo meras toras, que não têm conhecimento nem nesta nem naquela área, não sabem responder nem ajudar ninguém. (p. 319)

Segundo ele, na escola, o ensino deveria acontecer com prazer e por meio de brincadeiras. A posição apresentada é em favor de uma educação lúdica, resgatando o exemplo da educação grega cujo alto padrão, segundo ele, se infere das qualidades do povo que nela se forjou. Se os jovens gostam de dançar, cantar e pular e estão sempre em busca de algo que lhes dê prazer, então que as disciplinas sejam estudadas com prazer e brincando. Para Lutero, “os métodos didáticos devem adaptar-se à natureza da criança” (Nunes, 1980, p. 100).

Martin Volkmann atenta para o fato de que, ao orientar a forma de educar a juventude, Lutero dá ênfase à liberdade no processo educativo. Em prefácio do Catecismo menor, Lutero ressalta novamente que não se deve coagir ninguém à fé ou ao sacramento, destacando a liberdade do sujeito no seu processo educativo. Para Volkmann (1984), a “educação cristã, segundo o princípio de Lutero, é educação para a liberdade" (p. 104).

Em relação ao período de estudo, são apresentadas posições diferentes segundo o sexo: aos meninos, caberia a freqüência diária à escola por uma ou duas horas e, fora dela, deveria se aprender um ofício; já as meninas deveriam estudar por uma hora na escola e também cumprir com as tarefas domésticas. Segundo Hilsdorf (2006), esse pouco tempo destinado ao estudo era explicável, visto que se tratava de uma escola elementar em que o ensino era apenas religioso e voltado para a aprendizagem da doutrina.

Apesar da ênfase dada por Lutero à leitura da Bíblia e mesmo ao estudo das Sagradas Escrituras em alemão em benefício do trabalho de interpretação, no período da Reforma, ainda se manteve a tradição oral, presente na ldade Média. Assim, as escolas, sobretudo as elementares, teriam então continuado a tradição do aprendizado "mais pelo ouvir-dizer-fazer e a memorização do que pelo domínio da leitura e escrita" (Hilsdorf, 2006, p. 167).

Dessa mesma maneira, Jean-François Gilmont afirma que no século XVI há uma multiplicação de livros, mas essa multiplicação acontece em um mundo em que as relações são essencialmente orais. Lutero não somente não questiona essa tradição oral, o que era de se esperar dada sua ênfase na leitura e interpretação pessoal da Bíblia, mas a utiliza e defende nas igrejas. Segundo Gilmont (1997),

Ao passo que a criação das lgrejas protestantes está consumada, o final do século XVı não parece ter vivido uma revolução no modo de lidar com o escrito. No domínio religioso, o oral conserva seu lugar de destaque. [...] A preponderância da oralidade não parece, portanto, de forma alguma questionada pela Reforma. (p. 71)

Contudo, se é fato que a Reforma não questiona a oralidade, suas conseqüências podem não ter sido determinantes, mas contribuíram para o início de um processo de passagem de uma cultura oral para uma cultura da leitura e da escrita ou ao menos alteraram sua forma. Antônio Frago (1993) analisa essa questão situando-a em seu contexto histórico e social:

Ao difundir-se a alfabetização e o texto escrito, por intermédio da imprensa, mudam as relações com o mesmo: a função de mediador desaparece e as condições de comunicação, de coletivas, passam a ser individuais. [...] As duas vítimas desses processos são o velho e o padre. 0 primeiro perde a utilidade de sua memória; o segundo, o segredo de seu prestígio e o núcleo de seu poder como elo entre o escrito e o oral. (p. 34-35)

Esse autor defende posição semelhante à de Jean-François Gilmont sobre a não interferência da reforma na tradição da cultura oral 
e afirma que apesar de ser "inegável a coincidência no tempo, na Alemanha do século XV1, da Reforma com um crescimento da rede escolar e da alfabetização", seria naturalmente "errôneo conectar, no século XVI, a leitura da Bíblia em língua vulgar com a alfabetização" (Frago, 1993, p. 47). Contudo, apesar da cautela necessária em não se verificar na situação uma relação de causa-efeito, o autor não chega a esclarecer o que poderia ter contribuído para tal 'coincidência'.

Em relação à questão da oralidade na lgreja, Timothy George (1993) analisa a posição de Lutero e afirma que para ele "a igreja não era uma 'casa da escrita', mas uma 'casa da fala”' (p. 91), afinal o próprio Cristo nada tinha escrito, mas sim pregado pela palavra falada; e baseia-se, também, no ensinamento do apóstolo Paulo de que "a fé vem pelo ouvir e o ouvir pela Palavra de Deus"

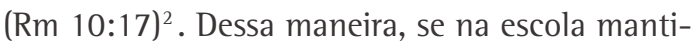
nham uma cultura oral, na lgreja, para o ensino da Palavra de Deus, ela era também mantida e indicada como a melhor maneira.

\section{Professores}

Nos dois textos analisados, Lutero (1995) enfatiza a relevância de mestres bem preparados. Reclama a falta de pessoas qualificadas para o ensino e adverte que "para ensinar e educar bem as crianças precisa-se de gente especializada” (p. 308). Ao discorrer sobre o tempo de ensino, uma ou duas horas para meninos e uma hora para meninas, aliado a uma ocupação, afirma que se alguém quisesse se tornar uma pessoa qualificada para o cargo de professor - juntamente com o de pregador ou outros cargos clericais -, deveria se dedicar a um estudo prolongado e intensivo ou até mesmo destinar exclusividade aos estudos.

No elogio que faz, em 1530, ao Conselho da cidade de Nürenberg pela fundação do Ginásio de Egídio, ele ressalta a relevância de terem escolhido e contratado as pessoas mais qualificadas, não tendo, na ocasião, nenhuma universidade tão bem provida de docentes, com mestres especializados para o ensino de grego, latim, hebraico, poética e matemática (Lutero, 1995).

Os professores deveriam, então, ser pessoas especializadas que tivessem se interessado e se disposto ao estudo por longo tempo, visto que essa profissão era muito valorizada por Lutero (1995):

De minha parte, se eu pudesse ou tivesse que abandonar o ministério da pregação e outras incumbências, nada mais eu desejaria tanto quanto ser professor ou educador de meninos. Pois sei que, ao lado do ministério da pregação, esse ministério é o mais útil, o mais importante e o melhor. Inclusive tenho dúvidas sobre qual deles é o melhor [...]. (p. 359)

\section{Financiamento}

É aos pais a quem Lutero se dirige e apela para que enviem os filhos à escola, mas é às autoridades das cidades a quem ele conclama para a criação e manutenção de escolas cristãs. A quem, de fato, se destinaria a responsabilidade pelo financiamento dessa educação escolar?

Em 1524, ele faz um apelo aos pais para que estes, além de enviarem seus filhos à escola, também contribuam com doações para seu sustento financeiro, argumentando que a resistência ou a má vontade em contribuir financeiramente para as escolas seria 'obra do diabo', afinal,

[...] até agora dispendeu inutilmente tanto dinheiro e bens com indulgências, missas, vigílias, doações, espólios testamentários, missas anuais para falecimentos, ordens mendicantes, fraternidades, peregrinações e toda a confusão de outras tantas práticas deste tipo; estando agora livre dessa ladroeira e doações para o futuro, pela graça de Deus, que doravante doe, por agradecimento e para a glória de Deus, parte

2. Bíblia Sagrada. Versão corrigida e revisada. São Paulo, 1994, p. 1229. 
disso para a escola, para educar as pobres crianças, onde está empregado tão bem. (Lutero, 1995, p. 305)

No entanto, Lutero não se apóia na dependência da boa vontade dos pais e não responsabiliza a lgreja por assumir essa tarefa educacional. Também não conclama os príncipes para essa tarefa o que, segundo Altmann (1994), seria o mais provável visto que "a imagem corrente do Reformador coloca-o na proximidade deles" (p. 203).

Propõe a responsabilidade aos conselhos municipais das diversas cidades da Alemanha, ou seja, o sustento econômico para a criação e manutenção das escolas seria de responsabilidade das instituições políticas locais, afinal: "A eles, como curadores, foram confiados os bens, a honra, corpo e vida de toda a cidade" (Lutero, 1995, p. 309).

Dessa maneira, visto que o progresso de uma cidade não se deve contabilizar pelo acúmulo de riquezas, mas por possuir cidadãos bem instruídos, os conselhos municipais deveriam despender de todo o recurso necessário para a criação e manutenção das escolas cristãs visando o seu próprio progresso.

\section{Princípios e fundamentos da Educação}

Da análise dos dois textos citados de Lutero, a carta de 1524 e o sermão de 1530, podese encontrar, ainda, discussões fundamentais sobre a educação escolar, algumas inovadoras, merecedoras de reflexão. Entre outras, encontram-se questões como: A que público essa escola deveria atender? Qual a utilidade do estudo oferecido por essa escola? Ela deve ser de caráter obrigatório? Quem deveria ser responsável pela oferta e supervisão dessa educação formal?

Algumas dessas questões não são simples de serem analisadas e há diferentes opiniões de autores que apresentam posições diferentes quanto ao que seria inovador nas propostas de Lutero. Optou-se novamente por, em um pri- meiro momento, expor o que há registrado nos textos citados para cada tema escolhido para aqui ser analisado e, posteriormente, apresentar a discussão que os autores realizam.

\section{Uma educação popular}

Em 1530, no apelo que faz aos pais para que enviem os seus filhos à escola, Lutero explicita que o seu objetivo é o de que todas as crianças recebam uma educação formal cristã, ou seja, que todas, independentemente do tipo de família a que pertençam, freqüentem a escola. Sendo assim, ele conclama os 'filhos dos patrões' e os 'filhos de gente pobre' para freqüentarem a escola.

Denuncia também o fato de as pessoas simples muitas vezes se preocuparem apenas em instruir os filhos quanto a um ofício para que possam contribuir financeiramente com o rendimento da família ou apresentarem uma preocupação única com sua alimentação e saúde, prejudicando-os por não os enviarem à escola.

Os filhos de gente pobre, portanto, também deveriam freqüentar a escola visto que possuíam capacidade para tal e poderiam, instruídos, servir a Deus:

Esses meninos capazes deveriam ser encaminhados ao estudo, especialmente os filhos da gente pobre, pois para essa finalidade foram instituídas as prebendas e tributos de todas as fundações e conventos. Naturalmente também os outros meninos deveriam aprender ao menos a entender o latim, a escrever e ler, mesmo que não fossem tão capazes; pois não precisamos somente de eruditos doutores e mestres na Escritura; também precisamos de pastores comuns, que preguem o Evangelho e o catecismo ao povo jovem e rústico, que batizem e administrem o sacramento etc. (Lutero, 1995, p. 342)

Já para os filhos dos que eram patrões na cidade, ou seja, daqueles que possuíam recursos e que talvez já tivessem oportunidade de ter uma educação formal como se dava no antigo modelo, 
ele conclama que também sejam enviados para a escola cristã; contudo, após receberem a instrução, poderiam exercer outros tipos de funções:

[...] não quero ter insistido que todos devem educar seus filhos para esse ministério, pois não é necessário que todos os meninos se tornem pastores, pregadores ou professores. E é bom saber que os filhos dos patrões e grandes senhores não se destinam a essa finalidade, pois o mundo também precisa de herdeiros e gente, do contrário se destroçaria a autoridade secular. (p. 342)

E essa instrução seria necessária pois,

[...] sabemos, ou deveríamos saber, o quanto é necessário e útil e o quanto agrada a Deus quando um príncipe, senhor, conselheiro ou outra pessoa que deve governar é instruída e apta para exercer essa função cristãmente. (p. 318)

Ainda que apresente uma utilidade diferente para a educação escolar dependendo da situação econômica e social das crianças, faz um grande esforço de proclamá-la como sendo uma educação para todos e não somente para uma pequena parcela da população ligada aos cargos eclesiásticos ou às famílias dos príncipes e dos que pertenciam a uma elite crescente na época. Todos deveriam freqüentar a escola, ainda que ela oferecesse um ensino diferenciado (o que não fica claramente explícito nos textos em questão) e, posteriormente, cargos distintos dependendo do tipo de população.

É baseado, sobretudo, nessa distinção que Lorenzo Luzuriaga (1959) entende que:

[...] o ensino pedido por Lutero é antes para a burguesia, para as classes que hão de prover os cargos de direção da sociedade: eclesiásticos, funcionários, médicos, advogados. 0 que exige para a educação do povo é muito elementar [...]. (p. 7)
Dessa forma, com esses preceitos, Lutero teria consagrado a

[...] tradição de encaminhar os nobres e a alta burguesia de comerciantes para os colégios, e os artesãos, negociantes e camponeses para a escola elementar popular e religiosa. (Hilsdorf, 2006, p. 168)

Das orientações de Lutero para a construção de boas bibliotecas, surgem as críticas de Jean-François Gilmont (1999), que ressalta o fato de ele ter atribuído aos magistrados também a tarefa de conservação dos livros e de permissão para que os dirigentes espirituais e temporais pudessem estudar. Ou seja,

[...] para Lutero, o objetivo da escola não é o acesso de todos à cultura. A escola tem por função formar uma elite capaz de dirigir tanto a sociedade civil quanto a religiosa. [...] Nada de leitura popular. (p. 54)

Nos escritos de Lutero, não se encontram evidências de uma proposta de diferentes escolas para as populações dependendo da classe a que pertenciam. Como já observado, o que se pode constatar são usos diferentes para o ensino escolar que ele propõe que todos freqüentem. Historiadores trazem essa divisão nas escolas por registros (que não os de Lutero) de observação de como as escolas passaram a se organizar no século XV1 a partir das interferências de Lutero, mas cabe ressaltar que, em seus escritos, não há nada que permita a afirmação de que ele teria planejado escolas distintas para distintas classes.

Não seria compreensível que no século XVl os colégios secundários em plena reorganização e a recém-fundação de novas escolas, para esse tipo de ensino, recebessem os filhos das camadas burguesas? Não seriam estes os que já teriam condições de acompanhar o ensino oferecido pelo colégio dos humanistas por já terem se iniciado nas 'primeiras letras' seja por meio da freqüência à antiga escola ou do 
contato com os professores itinerantes, profissionais contratados muitas vezes pelos pais?

Pode-se não encontrar respostas claras para essas questões, mas o que se torna importante destacar é que, independente da forma e do que se concretizou das propostas de Lutero, e mesmo se ele as tivesse realmente formulado dessa maneira, este propôs que todos freqüentassem a escola para serem instruídos na Palavra de Deus e agirem de forma cristã na sociedade, quer no âmbito espiritual como no secular.

Apesar dessa forte e clara posição não ser muito comum em seu tempo e ir contra uma longa experiência de ensino voltado apenas para a formação de sacerdotes e eclesiásticos, historiadores concordam que ele não foi o inaugurador na defesa de uma instrução escolar para todos, sendo que na época da Reforma já teria havido algumas manifestações a favor de uma educação popular.

Nunes (1980) afirma que "de forma alguma as escolas elementares surgiram por iniciativa de Lutero" (p. 100) e relata as fases da congregação dos Irmãos da Vida Comum (fraternidade fundada por clérigos pobres) que desde 1400 começaram a ensinar crianças e dirigir escolas elementares e que, a partir de 1450, converteram suas casas em ginásios e passaram a aplicar as idéias humanistas.

0 autor ainda relata que, no que diz respeito ao ensino elementar, as cidades italianas já se destacavam desde o final da ldade Média, sendo que até mesmo os vilarejos dispunham de escolas nas quais se instruíam grande parte da população urbana (Nunes, 1980). Essas escolas também já se adiantavam por serem financiadas pelas suas próprias cidades e não mais por instituições religiosas.

Da mesma maneira, Lorenzo Luzuriaga (1963) faz uma avaliação do que, ao terminar o século XV1, compunha a educação na Alemanha e apresenta três tipos de escolas: as escolas primárias ou elementares "para o povo, nas aldeias e pequenas localidades, com ensino muito elementar dado na língua alemã, por eclesiásticos ou sacristãos, e com caráter principalmente religio- so"; as escolas secundárias ou colégios humanistas, "para a burguesia, de caráter humanista, mas também religioso, como preparação principalmente para os cargos eclesiásticos e profissões liberais"; e as universidades e escolas superiores, umas "transformadas no espírito da religião reformada, e outras, de nova criação dos príncipes protestantes" (p.111).

Diante das propostas de Lutero e da constatação de historiadores, o que se conclui é que este pode não ter sido realmente o primeiro a se preocupar com uma educação popular. Entretanto, segundo Manacorda (1989), é evidente que o impulso prático que ele deu e sua força política foram os responsáveis pelos novos progressos. Nunes (1998) corrobora essa constatação afirmando que

[...] nas regiões em que se implantou a reforma de Lutero ou Calvino, ao lado do amor pelos clássicos, surgiu o interesse pela educação popular, devido ao preceito do estudo da Bíblia, que foi primordial para os adeptos da Reforma Protestante. Daí as escolas populares do tipo elementar e secundário. (p. 54)

\section{Uma educação pública}

Segundo Lutero, a responsabilidade pela educação escolar, um direito-dever de todos, deveria ser transferida do âmbito da Igreja para o do Estado, mais especificamente para as autoridades municipais. Essas instâncias políticas locais deveriam ser as responsáveis pela criação, pela manutenção e pelo financiamento das escolas e pela supervisão dos pais, garantindo que eles enviassem de fato os filhos à escola. Lutero (1995) afirma claramente:

[...] será da competência do conselho e das autoridades dedicar o maior cuidado e o máximo empenho à juventude [...] o melhor e o mais rico progresso para uma cidade é quando possui muitos homens bem instruídos, muitos cidadãos ajuizados, honestos e bem-educados. (p. 309) 
As autoridades municipais deveriam ser, portanto, as responsáveis pelo oferecimento das escolas cristãs, visto que seriam elas próprias as mais beneficiadas e, caso se negassem a cumprir essa tarefa, as próprias culpadas pelo falta de sucesso, "pois de quem é a culpa se hoje são tão raras nas cidades as pessoas bem preparadas, senão das autoridades?" (p. 310).

Para ele, tanto o financiamento e a organização quanto a supervisão das escolas deveriam ser de responsabilidade pública. Mário Manacorda (1989) ressalta como benefício da Reforma a sua capacidade de relacionar escola e cidade, instrução e governo e afirma:

Testemunho da força também educativa da Reforma no plano político é o fato de que a própria autoridade imperial teve de assumir esta nova concepção de uma escola pública para a formação dos cidadãos ou, pelo menos, dos governantes. [...] é, porém, de grande importância histórica a tomada de consciência do valor laico, estatal da instrução, concebida não mais como algo reservado aos clérigos, mas como fundamento do próprio Estado. (p. 199)

Luzuriaga (1959) é ainda mais enfático nesse ponto e chega a afirmar que "a educação pública, isto é, a educação criada, organizada e mantida pelas autoridades oficiais - municípios, províncias, Estados - começa, como dissemos, com o movimento da Reforma religiosa no século XVl” (p. 5). Ele identifica Lutero, ainda, como "o primeiro a chamar a atenção, de modo insistente, para a necessidade de criar escolas por meio das autoridades públicas" (p. 6, grifos meu).

Em um estudo sobre a origem da escola pública, Eliane Lopes (1981), apesar de situar como conquista da Revolução Francesa os princípios de universalidade, gratuidade, laicidade e obrigatoriedade que compõem a escola pública como a que se concebe hoje, afirma que "modernamente, a educação tornase pública nos países atingidos pelo movimento da Reforma” (p. 14).
Entretanto, essa visão é amplamente rebatida na historiografia mais atual, pois já havia, como já mostrado, experiências de oferecimento de ensino pelas comunas italianas onde, desde o século XIV, elas cobriam os salários dos professores oferecendo aulas gratuitas. Nunes (1980) relata que no final da ldade Média, em cada cidade da ltália e até nos vilarejos, havia escolas e

[...] as próprias comunas rurais nada ficavam a dever aos grandes centros, já que fundaram escolas e pagaram professores para os meninos aprenderem a ler, escrever, assim como a conhecer um pouco de latim. Embora as crianças não freqüentassem regularmente a escola no meio rural, o nível cultural da população campesina era superior ao de outros países europeus. (p. 66)

Hilsdorf (2006) também relata essas experiências como fator histórico para comprovar que Lutero não foi o primeiro a idealizar uma educação pública. Ela afirma que ele

[...] não criou a escola elementar popular e pública, como diz a historiografia da educação: antes dele, ela já era uma tradição escolar da Europa, inclusive no sentido de que o seu controle era assumido em parte pelas autoridades das cidades. (p. 168)

Se há provas de que Lutero não foi o precursor na iniciativa por uma educação elementar popular e pública, talvez ele tenha se destacado pelo seu 'modo insistente', como relatou Luzuriaga (1959), de apelar às autoridades. Nunes (1998) aponta a iniciativa de Lutero em relação à responsabilidade pública para educação secundária afirmando que: "a escola média começou a ser custeada pelos cofres públicos e ser mantida pelo Estado nos países protestantes"; porém, os estabelecimentos eram essencialmente religiosos, sendo que "só no século XVIII, na Alemanha, começou a educação pública puramente estatal com os reis da Prússia, Frederico Guilherme 1 e Frederico 11, o Grande” (p. 55). 
Teria Lutero recorrido ao Estado para a responsabilidade pela tarefa educacional apenas para assegurar o sucesso de suas propostas? Que garantias tinha ele de que isso aconteceria? Por que recorrer às autoridades locais e não aos príncipes? As respostas a essas indagações não são simples, dado que a própria noção de Estado, caminhando-se para a formação de um Estado moderno, estava sendo reformulada e a relação de Lutero com o Estado se apresenta como um aspecto de análise complexa.

Contudo, cabe relembrar que, para Lutero, o Estado possuía um caráter cristão e este deveria assumir um papel em prol da paz e justiça do povo governando como a mão esquerda de Deus. Nesse sentido, talvez fosse natural que a lgreja em decadência tivesse que deixar de ser a organizadora e mantenedora da educação escolar e, em seu lugar, o Estado se ocupasse dessa tarefa para promover uma educação cristã, que instruísse as crianças e os jovens para se tornarem religiosos que atuariam tanto na esfera espiritual como também na secular.

Ao refletir sobre o caráter estatal que Lutero atribui à educação, Walter Altmann (1994) sugere algumas questões relevantes: por que teria atribuído a responsabilidade da educação às autoridades das cidades e não aos príncipes? Ele responde em favor de Lutero defendendo essa posição como progressista:

[...] o chamamento de Lutero às autoridades municipais e à nova burguesia emergente, no sentido de que assumissem a responsabilidade da educação, foi um passo nitidamente progressista. Lutero mostrou aguda sensibilidade quando, nessa questão, não apelou simplesmente para a autoridade dos príncipes, mas chegou bem mais perto da base do cotidiano, escolhendo as autoridades municipais, mais diretamente ligadas com as necessidades concretas de seus habitantes. De fato, foi uma escolha que veio a se comprovar como correta, pela ampliação das oportunidades educacionais. (p. 208)
Contudo, além dessa afirmação se mostrar marcada por uma visão do presente, o mesmo autor reflete sobre uma conseqüência negativa que resultou dessa escolha ao se convocar as autoridades municipais para assumirem a responsabilidade pela educação: as cidades que já estavam em franco desenvolvimento só tenderam a prosseguir com os ganhos educacionais. Entretanto, nas áreas rurais, que não tinham muitas condições de acesso à educação escolar, a proposta teria sido menos exeqüível.

Contribui para uma melhor compreensão relembrar o fato de a Alemanha se encontrar dividida em cidades independentes, o que permitiu, com o desenrolar do movimento da Reforma, que por algum momento cada autoridade escolhesse a religião de seus súditos. Sendo assim, cada local teve que optar pelo apoio à lgreja Católica ou à Reforma e, no caso de apoio a esta, era compreensível o fato de que precisavam atender às propostas educacionais propagadas por Lutero.

Entretanto, havia a possibilidade de príncipes que pudessem não ter aderido aos ideais da Reforma e daí, talvez, se justifique o fato de Lutero convocar o Conselheiro de cada cidade para atentar à sua proposta de criação e manutenção de escolas como responsabilidade das autoridades locais e não mais da lgreja, tentando convencê-los de que os mais beneficiados com essa atitude seriam as próprias cidades.

Outro argumento que pode explicar o fato de Lutero ter convocado as autoridades locais e não os príncipes para a responsabilidade pela tarefa educacional é o próprio exemplo do que vinha ocorrendo na ltália com as já citadas comunas italianas em que as autoridades de cada local financiavam professores para as crianças quando os pais não podiam fazê-lo. Ou mesmo o fato de que a Alemanha encontrava-se dividida em diversos territórios marcados pela disputa de terras e o poder dos príncipes locais muitas vezes sobrepunha o poder formal do imperador. Entretanto, apesar das hipóteses apresentadas, evidenciou-se a necessidade de estudos mais aprofundados, específicos sobre esse tema, para que se alcance uma conclusão consistente. 


\section{Qual a utilidade da educação}

A proposta de Lutero em relação às escolas é a de que elas sejam cristãs e atendam a todos, e essa educação por ele defendida apresenta objetivos bem definidos: tem sua utilidade prática para a preparação de ministros e de bons administradores da casa, mas é, sobretudo, uma utilidade social a que Lutero explicita como resultado dessa instrução.

Com seu próprio exemplo e baseado na doutrina dos dois reinos, convoca os cristãos para participarem ativamente do mundo em que se encontram e contribuírem para que se tornem mais cristão. Esse posicionamento diante do curso do mundo, com o temor de Deus, só poderia acontecer mediante uma nova educação que é a que ele propõe.

Cambi (1999) afirma que a concepção pedagógica de Lutero "baseia-se num fundamental apelo à validade universal da instrução, a fim de que todo homem possa cumprir os próprios deveres sociais" (p. 249). Para isso, as escolas cristãs deveriam ser criadas e mantidas, para que as crianças e os jovens aprendessem as ciências, a disciplina e o verdadeiro culto a Deus de forma que, posteriormente, elas pudessem se tornar "pessoas capazes de governar igrejas, países, pessoas, casas, filhos e criadagem" (Lutero, 1995, p. 330).

Manacorda (1989) ressalta essa utilidade social da instrução em Lutero que, segundo sua análise, era

[...] destinada a formar homens capazes de governar o Estado e mulheres capazes de dirigir a casa, segundo uma divisão do trabalho entre os sexos, divisão que, embora não revolucionária, pelo menos é realista. (p. 197)

Da instrução, dependia também a continuidade de existência do ministério e do estado eclesiástico, o que faz Lutero apelar para que os pais enviem seus filhos para a escola para que estes não venham a cair no abando- no e, com isso, o mundo sofra com a falta de pessoas que preguem a Escritura.

Sendo assim, um filho educado e instruído em uma escola cristã poderia ser muito útil à causa de Cristo e a toda a sociedade:

[...] ele também realiza tão-somente grandes e importantes obras em favor do mundo: ensina e instrui todas as categorias sociais como se devem conduzir exteriormente em seus cargos e suas posições, para agirem com justiça perante Deus. (Lutero, 1995, p. 338)

Lutero ainda segue dizendo que não haveria problemas se um menino que estudou aprendesse um ofício e se tornasse um cidadão, ou seja, que o estudo não atrapalharia seu trabalho, mas, antes, o ajudaria a administrar melhor sua casa e estaria apto para o ministério da pregação ou do pastorado caso precisassem dele.

Aliás, como já ressaltado, o aprendizado de um ofício era recomendado aos meninos e a tarefa doméstica, às meninas, após o período de aula. Dessa forma, com a Reforma, criaram-se "escolas elementares que conciliavam o aprendizado da língua com a formação para atividades produtivas" (Hilsdorf, 1998, p. 29). No entanto, os pais não deveriam permitir que as crianças aprendessem apenas o suficiente para exercer uma atividade rentável, ou seja, não bastaria apenas aprender a contar e a ler, pois "para aprender a pregar, governar e administrar a justiça, tanto no estado clerical ou secular, não bastam sequer todas as ciências e línguas do mundo [...]" (Lutero, 1995, p. 328).

Dessa forma, se os pais queriam agradar a Deus e contribuir para o sucesso futuro da cidade, deveriam enviar os filhos para a escola de forma que a instrução os tornasse pessoas úteis à propagação da palavra de Deus e à toda a sociedade, independente da função que exerceriam.

\section{Uma educação obrigatória}

Lutero não somente faz um apelo para que se criem e mantenham escolas cristãs e 
para que os pais enviem seus filhos a essas escolas. A educação escolar não deveria depender apenas da adesão ou aceite ao seu apelo quanto aos benefícios que a instrução escolar poderia proporcionar. Ele defende que a educação escolar, além de ser para todos, tenha um caráter obrigatório, forçando os pais e as autoridades atentarem para ela.

Cambi (1999) ressalta que, "com o protestantismo, afirmam-se em pedagogia o princípio do direito-dever de todo cidadão em relação ao estudo, pelo menos no seu grau elementar, e do princípio da obrigação e da gratuidade da instrução" (p. 248). Se a história revela que antes de Lutero já havia pessoas que defendiam uma educação popular, ela nada revela sobre a obrigatoriedade do ensino, o que leva a pensar que esse avanço na reivindicação da educação elementar tenha Lutero com um dos pioneiros.

Ele afirma aos pais que é mandamento de Deus, por meio de Moisés, que eles instruam os filhos e que, no seu ponto de vista, não haveria pecado que merecesse maior castigo que o cometido contra as crianças quando deixam de educá-las. No entanto, como afirma que para ensinar e educar bem as crianças é preciso gente especializada, a obrigação dos pais seria, então, enviá-los à escola.

Ameaça os pais dizendo que, se eles não cumprissem sua obrigação de encaminhar os filhos à escola, se tornariam os responsáveis caso o serviço de Deus se arruinasse; e também os relembra de que não são os donos absolutos de seus filhos, pois estes também pertencem a Deus e por isso devem entregá-los para Ele, enviando-os à escola de forma a garantir sua instrução que muito poderia contribuir para a obra cristã.

No que se refere aos recursos financeiros necessários para essa educação, ele orienta os pais para que esse não seja um motivo de preocupação ou de recusa no envio dos filhos para a escola, afirmando que antes faltarão pessoas do que recursos. Contudo, ainda que isso aconteça, ou seja, ainda que faltem recursos para a instrução de seus filhos, relembra que ele mesmo havia sido um mendicante para conseguir realizar seus estudos até seu pai ter condições de sustentá-lo e dá o seguinte conselho aos pais:

[...] manda teu filho estudar com toda confiança. Ainda que, por enquanto, tenha que ficar mendigando pão, estás oferecendo a Deus nosso Senhor uma madeira preciosa da qual pode talhar-te um senhor. (Lutero, 1995, p. 357)

Dessa maneira, não havia motivo ou desculpas para que qualquer criança deixasse de receber a instrução escolar. Todas deveriam ser enviadas à escola e aos pais caberia essa responsabilidade. Conclama, ainda, as autoridades para que essa obrigação seja de fato cumprida: "Em minha opinião, porém, também as autoridades têm o dever de obrigar os súditos a mandarem seus filhos à escola [...]" (p. 362), além de serem as responsáveis pela criação e manutenção dessas escolas.

Assim, cabia às crianças a obrigatoriedade de freqüência à escola, e às autoridades, a sua garantia e supervisão. Segundo Luzuriaga (1959),

A principal característica dessa educação pública religiosa, [...] é seu apelo às autoridades (e a resposta delas) no sentido da fundação de escolas mantidas com recursos públicos e do estabelecimento de freqüência obrigatória. (1959, p. 6, grifos meu)

A educação encontra em Lutero o seu primeiro defensor de uma escola que fosse ao mesmo tempo para todos, de freqüência obrigatória e como responsabilidade (de financiamento e supervisão) das autoridades leigas e não mais religiosas. Ao defender essa escola pública cristã, ele coloca a instrução como sendo, "portanto, uma obrigação para os cidadãos e um dever para os administradores das cidades" (Cambi, 1999, p. 249).

Sendo assim, os princípios de uma educação popular, gratuita e obrigatória e de ca- 
ráter estatal podem ser encontrados já no século XVI nas propostas de Lutero para a educação no movimento da Reforma Protestante.

\section{Considerações finais}

Uma reflexão sobre a atuação de Lutero no contexto educacional não deve estar distanciada de seu contexto histórico e dos seus objetivos iniciais que se encontravam, sobretudo, no âmbito religioso. A educação era tema tratado por estudiosos da época e, posteriormente, assim o foi principalmente por aqueles que se intitulavam humanistas. Entretanto, compreender o que levou Lutero a apresentar propostas educacionais inovadoras - que se não o foram na criação, sem dúvida o foram na forma de sua proposição para seu tempo -, que repercutiram ao longo da história, não se mostra uma tarefa de fácil realização.

Talvez a primeira questão a ser posta é se Lutero se propunha ser um reformador da educação da mesma maneira como se colocou para a lgreja. Era seu objetivo reformar a educação escolar ou essa proposta surgiu como conseqüência e extensão de sua reforma na Igreja? Alguns autores o vêem como um reformador da educação e até mesmo analisam suas ações como as de um pedagogo. Contudo, outros, como Altmann (1994), consideram-no sobretudo um reformador religioso que acabou afetando o campo educacional por ser o processo educativo intrínseco ao ser humano.

Sem se propor a questionar o fato de religião e educação serem ou não processos inerentes ao ser humano ou ainda a relação que há entre elas, o que se mostra necessário ressaltar é que Lutero foi, como bem observa Geoffrey Elton (1982), um homem profundamente religioso e teólogo de formação e, sendo assim, suas ações em prol da reforma estavam dentro do domínio da religião e da teologia, sendo que "quaisquer que sejam os outros efeitos e tributários da história, esse é o ponto de que se deve partir” (p. 220).

Contudo, se as suas preocupações centravam-se no campo religioso e teológico, por que ele teria se levantado para propor uma nova organização do sistema escolar e ainda convocado autoridades e pais para atentarem para essa educação? Para refletir sobre essa questão, é necessário ressaltar que as idéias educacionais de Lutero e todo o movimento da Reforma Protestante não devem ser analisados fora dos acontecimentos de sua época. Nesse sentido, outras perguntas se juntam à anterior: teria Lutero interferido na educação influenciado pelos ideais humanistas que se propagavam pela Europa e diante dos quais ele aproveitava para criticar ainda mais a escolástica em que fora educado?

A relação de Lutero com os humanistas e sua posição em relação a esses ideais indica não ser consenso entre os autores que ou aceitam essa aproximação ou a negam, atribuindoa muito mais ao humanista Filipe Melanchthon. No entanto, essa posição de Lutero de aceitação de novos ideais concomitante com a sustentação de algumas práticas conservadoras e medievais reflete o próprio contexto em que ele estava inserido dentro de um período de transição entre a ldade Média e o início da ldade Moderna.

No entanto, em relação aos ideais humanistas, o que se questiona é se estes seriam suficientes para provocar as transformações na educação independentemente das ações de Lutero ou de outros personagens dentro do movimento da Reforma ${ }^{3}$. Se a força da mudança intelectual estava no Renascimento, por que os progressos educacionais, no sentido da criação de um sistema escolar público e popular que impactasse outros locais, não saíram da Itália e França nos séculos em que se iniciou a corrente renascentista?

Pode ser que alguns fatores tenham auxiliado Lutero nas suas conquistas educacionais como: o fato de ele ter se tornado notório em sua luta pela Reforma da lgreja e, além da relação próxima que já tinha com as autoridades, ao

3. Geoffrey Elton (1982), ao escrever sobre as divergências entre Lutero e Erasmo, faz esse questionamento em relação às mudanças na Igreja: "0 que consta é saber se a Reforma de Lutero era realmente necessária ou se a Igreja podia ter sido renovada e restabelecida pelo vasto movimento do humanismo cristão que se inspirava em Erasmo e que (como vimos) sem dúvida contribuiu para preparar o terreno para os ataques mais drásticos contra o protestantismo" (p. 226). 
se tornar uma figura pública, suas reivindicações e seus apelos talvez tenham tido maior repercussão. Pode ser que o seu objetivo realmente fosse o de ensino da doutrina e então ele não teria medido esforços para a construção de uma proposta educacional que o auxiliasse na conquista com êxito de seu propósito religioso.

A tentativa de fundamentar esse argumento de interesse no ensino da doutrina pode se encontrar no fato de que Lutero realmente defendia que as autoridades financiassem uma educação que fosse cristã, além do fato de que historiadores indicam o uso dos Catecismos por ele escritos nas escolas elementares. Contudo, não parece ter sido esse o único nem o principal objetivo de Lutero e, se assim o foi, não encontrou nele êxito, afinal, sua figura é amplamente associada à criação de uma escola elementar e popular e não de uma escola doutrinária que se espalhou pelos territórios, moldando pessoas para a religião protestante.

A análise dos textos escritos em 1524 e 1530 evidencia que ele se preocupou com uma nova organização das escolas. Ele não explicita exatamente o que era destinado para o ensino elementar e para o secundário, mas propõe um ensino baseado nas línguas (a vernácula para o ensino elementar e as clássicas e o hebraico para o secundário, segundo os historiadores) e na leitura da Bíblia. As alterações sugeridas para o currículo e os métodos mostram uma tentativa de inserir o novo - dos humanistas - com continuidades do antigo sistema escolástico. A preocupação com o tempo destinado ao ensino, tipo de professores, forma de financiamento, entre outros, evidenciam a preocupação com a estruturação de um sistema de ensino diferente e até mesmo a criação do oferecimento de uma 'modalidade' de educação escolar que não existia nas cidades alemãs, como foi o caso das escolas elementares.

Há críticas de que as escolas elementares se destinariam a um público popular para ensino da doutrina e de preparação para o trabalho no comércio, enquanto os colégios secundários se destinariam para as classes bur- guesas, preparando os alunos para ingresso na Universidade. Contudo, apesar de no texto de 1524 Lutero propor que as crianças aprendam um ofício, isso não parece fundamentar o argumento exposto acima, pois se pode constatar, no sermão escrito em 1530 (após o episódio da guerra dos camponeses que teria levado Lutero a repensar suas propostas para as camadas populares), que ele insiste para que os pais não deixem de enviar os filhos à escola e assim deixá-los trabalhando no comércio.

Dessa maneira, mostra-se inquestionável a reivindicação de Lutero para que a escola seja aberta a todos. Independentemente de objetivos e propostas de ensino diferenciadas, todas as crianças deveriam freqüentar uma escola financiada e mantida pelas autoridades locais. E talvez esteja aí, em um apelo pela criação de uma escola pública e estatal, com as particularidades que envolviam o Estado alemão naquele período, uma das maiores contribuições de Lutero para o sistema de ensino. E se a história mostra que houve antecedentes também nesse caso, como é o das comunas italianas do século XIV, convém reconhecer e analisar o ‘impulso prático', como descreveu Manacorda (1989), que deu a elas.

Porque, se encontramos na Revolução Francesa do século XV11l os princípios de gratuidade, obrigatoriedade, universalidade e laicidade do ensino que se espalharam por todos os lugares e constituíram o que hoje se chama de escola pública, foi antes, em Lutero, que encontramos uma defesa por uma educação gratuita, universal e obrigatória que se espalhou como apelo a todas as autoridades e não se restringiu a experiências locais sem repercussão (como se pode perceber no caso das comunas italianas, pois apesar de as autoridades locais atentarem para a necessidade de financiamento da educação escolar, não há indícios de que tenham repercutido por todo o território italiano e fora dele nem ganharam um 'impulso' insistente para sua propagação como foi o dado por Lutero no caso alemão).

Com isso, volta-se à questão das propostas educacionais de Lutero estarem ligadas 
e envoltas em sua luta maior pela reforma religiosa. Teria ele conseguido uma resposta positiva das autoridades, que atenderam ao seu apelo e construíram escolas, se tivesse apenas se levantado por uma luta pela reforma do ensino de sua época? Não é o que parece. A reforma e a construção de um novo sistema educacional para Lutero aparecem intimamente ligadas à sua proposta de reforma do âmbito religioso e de mudanças na sociedade. 0 Estado para ele era confessional, ou seja, deveria ser um Estado cristão, e daí o seu apelo para que ele interferisse tanto na religião quanto na educação da população. E se essa posição cristã era o que ele entendia ser a base do Estado e de toda a sociedade, não havia como ser diferente com a educação que deveria ser cristã e, assim, estar relacionada à religião em uma forma até mesmo de dependência recíproca.

Cabe ressaltar que a própria noção de Estado estava em reformulação e, talvez, também se encontre aí outra grande contribuição de
Lutero: para a criação de um Estado forte e auto-suficiente, caberia a ele a responsabilidade pela educação escolar de seus cidadãos. Se nesse período encontra-se o nascimento do Estado moderno, Lutero pode em muito ter contribuído apelando para que ele, e não mais a lgreja ou outra instituição religiosa, fosse o responsável pela oferta e manutenção de escolas que atendessem a todos. Sendo assim, nasce um Estado que deve ser consciente de que é seu dever proporcionar a todos o direito à Educação.

Para concluir, não há como não reconhecer o avanço dado por Lutero no que diz respeito ao direito à Educação de todos. Pode ele não ter sido o primeiro a criar (pelo exemplo das comunas italianas e da Congregação dos Irmãos da Vida Comum) nem o executor (não se deve esquecer Filipe Melanchthon) de tais propostas, contudo, foi ele um grande propugnador e defensor, junto às autoridades e à população, da criação de escolas que não atendessem somente aos clérigos e religiosos, mas que fossem abertas a todos.

\section{Referências bibliográficas}

ALTMANN, W. Lutero e libertação. São Paulo: Ática, 1994.

BECK, N. Igreja, sociedade e educação: estudos em torno de Lutero. Porto Alegre: Concórdia, 1988.

CAMBI, F. 0 século XVI: o início da pedagogia moderna. Tradução Álvaro Lorenci. História da Pedagogia. São Paulo: UNESP, 1999.

ELTON, G. R. A Europa durante a reforma: 1517-1559. Lisboa: Presença, 1982.

FOULQUIÉ, P. A Igreja e a Educação: com a Encíclica sobre Educação. Tradução Maria das Dores Ribeiro Figueiredo e Castro. Rio de Janeiro: Agir, 1957.

FRAGO, A. V. Do analfabetismo à alfabetização: análise de uma mutação antropológica e historiográfica. In: na sociedade e na história: vozes, palavras e textos. Porto Alegre: Artes Médicas, 1993. p. 29-68.

Alfabetização

GEORGE, T. Ansiando pela graça: Martinho Lutero. In: Teologia dos reformadores. São Paulo: Vida Nova, 1993. p. 54 - 107.

GILMONT, J.-F. Reformas protestantes e leituras. In: CAVALLO, G.; CHARTIER, R. (Orgs.). História da leitura no mundo ocidental. São Paulo: Ática, 1999. p. 47-116.

HILSDORF, M. L. S. Pensando a educação nos tempos modernos. São Paulo: EDUSP, 1998.

0 aparecimento da escola moderna: uma história ilustrada. Belo Horizonte: Autêntica, 2006.

LASKI, H. J. 0 liberalismo europeu. São Paulo: Mestre Jou, 1973.

LOPES, E. M. T. Origens da educação pública: a instrução na revolução burguesa do século XVIII. São Paulo: Loyola, 1981. 
LUTERO, M. Aos conselhos de todas as cidades da Alemanha para que criem e mantenham escolas cristãs [1524]. In: Martinho Lutero: obras selecionadas. São Leopoldo: Comissão Interluterana de Literatura, 1995, v. 5, p. 299-325.

Uma prédica para que se mandem os filhos à escola [1530]. In: Leopoldo: Comissão Interluterana de Literatura, 1995, v. 5, p. 326-363.

Martinho Lutero: obras selecionadas. São

Educação e Reforma. São Leopoldo: Sinodal; Porto Alegre: Concórdia, 2000. Coleção Lutero para hoje.

LUZURIAGA, L. A educação religiosa reformada. In: 124.

História da educação e da pedagogia. São Paulo: Nacional, 1963. p. 108-

A educação pública religiosa. In: História da educação pública. São Paulo: Nacional, 1959. p. 5-22.

MANACORDA, M. A. A educação no Quinhentos e no Seiscentos. In: dias. São Paulo: Cortez/Autores Associados, 1989. p. 193-257.

História da Educação: da antiguidade aos nossos

NUNES, R. A. da C. História da Educação no Renascimento. São Paulo: EPU, 1980.

Evolução da instituição escolar. In:

Estrutura e funcionamento da educação básica - leituras. São Paulo: Pioneira, 1998. p. 45-55.

VOLKMANN, M. Lutero e a Educação. In: DREHER, M. (Org.). Reflexões em torno de Lutero. São Leopoldo: Sinodal, 1984. v. 2.

\section{Obras consultadas}

COOPER, J. W. The outlines of political theology in the Protestant Reformation. In: Hills, CALIF: Fall, 1982. v. 10, n.1.

Teaching Political Science. Beverly

D’AUBIGNÉ, J. H. M. História da reforma do décimo-sexto século. Nova York: Sociedade de Tractados Americana, s.d. vol I.

ELIAS, N. Sobre a sociogênese do Estado. In: Jorge Zahar, 1993. v. 2. 0 processo civilizador: formação do Estado e Civilização. Rio de Janeiro:

GREN, V. H. H. Renascimento e Reforma: a Europa entre 1450 e 1660. Lisboa: Dom Quixote, 1984.

HIBLER, R. W. Martin Luther, The Educator. The Educational Forum, Spring 1985, v. 49, n. 3.

LUTERO, M. Pelo Evangelho de Cristo: obras selecionadas de momentos decisivos da Reforma. São Leopoldo: Comissão Interluterana de Literatura, 1984.

Política, fé e resistência. São Leopoldo: Sinodal; Porto Alegre: Concórdia, 2000; Coleção Lutero para hoje.

Da liberdade do cristão (1520): prefácios à Bíblia. Trad. Erlon José Paschoal. São Paulo, UNESP, 1998.

MAQUIAVEL, N. 0 príncipe. Rio de Janeiro: Paz e Terra, 1996.

WEBER, M. A ética protestante e o espírito do Capitalismo. 13 ed. São Paulo: Pioneira, 1999.

Recebido em 28.09.05

Modificado em 22.03.06

Aprovado em 22.05.06

Luciane Muniz Ribeiro Barbosa é pedagoga; aluna do programa de pós-graduação da FEUSP - mestrado, na área de Estado, Sociedade e Educação, sob orientação do Prof. Dr. Romualdo Luiz Portela de Oliveira; e professora na Faculdade Montessori de Educação e Cultura (FAMEC) e Universidade Bandeirantes (UNIBAN), no curso de Pedagogia. 